\title{
Indigenous Knowledge Transfer among Dusuns and Bajaus in Kota Belud, Sabah, Malaysia: Approaches and Challenges
}

Anis Amalina Adam, Normala Othman, Adlina Ab. Halim

To Link this Article: http://dx.doi.org/10.6007/IJARBSS/v11-i11/11656

DOI:10.6007/IJARBSS/v11-i11/11656

Received: 01 September 2021, Revised: 03 October 2021, Accepted: 19 October 2021

Published Online: 07 November 2021

In-Text Citation: (Adam et al., 2021)

To Cite this Article: Adam, A. A., Othman, N., \& Halim, A. A. (2021). Indigenous Knowledge Transfer among Dusuns and Bajaus in Kota Belud, Sabah, Malaysia: Approaches and Challenges. International Journal of Academic Research in Business and Social Sciences, 11(11), 1722-1734.

Copyright: (c) 2021 The Author(s)

Published by Human Resource Management Academic Research Society (www.hrmars.com)

This article is published under the Creative Commons Attribution (CC BY 4.0) license. Anyone may reproduce, distribute, translate and create derivative works of this article (for both commercial and non0-commercial purposes), subject to full attribution to the original publication and authors. The full terms of this license may be seen at: http://creativecommons.org/licences/by/4.0/legalcode

Vol. 11, No. 11, 2021, Pg. $1722-1734$

Full Terms \& Conditions of access and use can be found at http://hrmars.com/index.php/pages/detail/publication-ethics 


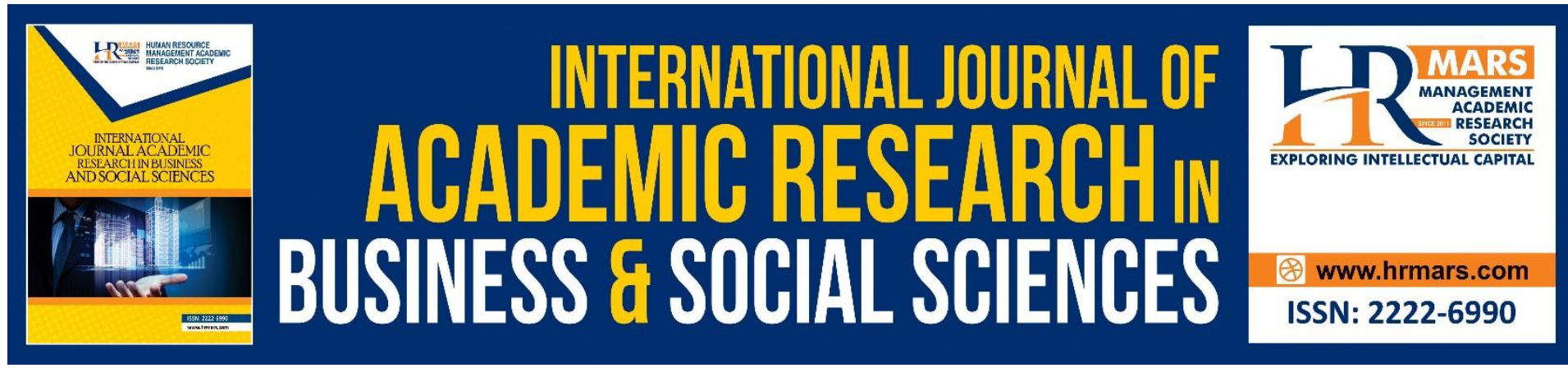

\title{
Indigenous Knowledge Transfer among Dusuns and Bajaus in Kota Belud, Sabah, Malaysia: Approaches and Challenges
}

\author{
Anis Amalina Adam, Normala Othman, Adlina Ab. Halim \\ Department of Government and Civilisation Studies, Faculty of Human Ecology, Universiti \\ Putra Malaysia, 43400 Serdang, Selangor, Malaysia \\ Email: normala_o@upm.edu.my
}

\begin{abstract}
Indigenous knowledge is a knowledge system uniquely belonged to a particular indigenous group. Indigenous knowledge is tacit in nature as its transfer is implied through actions or statements. It is inherited from generations to generations mainly by oral traditions such as folklores, traditional songs and dances, myths, and rituals. Therefore, this study aimed to explore the approaches in transfer of indigenous knowledge related to practices in biodiversity conservation among Dusuns and Bajaus. This study applied qualitative research design, which was carried out in Kota Belud, Sabah. Semi-structured interviews and focus group discussion were employed to collect primary data with six informants $(n=6)$. The data was then thematically analysed with the aid of Nvivo 8 . The findings of this study revealed that the transfer of indigenous knowledge occurred in collaboration with relevant parties, establishment of cultural sites, implementation of cultural law, and social events. In light of this, this study also discovered challenges that hindered the transfer of indigenous knowledge such as change of indigenous livelihood practices, change of religious beliefs, contact with dominant and non-indigenous groups, and economic development pressure. Finally, this study concludes with recommendations for comprehensive management of indigenous knowledge that supported sustainable practices in biodiversity conservation.
\end{abstract}

Keywords: Bajau, Dusun, Indigenous Knowledge Transfer, Customary Law, Religious Belief

\section{Introduction}

Indigenous knowledge is a knowledge system uniquely belonged to a particular indigenous group or tribe. Indigenous knowledge is tacit in nature as its transfer is implied through actions or statements. It is passed down from generations to generations mainly by oral traditions such as folklores, traditional songs and dances, myths, and rituals (United Nations, 1992). Upon its recognition by academicians and international institutions, indigenous knowledge has become an important facet in various fields including biodiversity conservation (Berkes, 2008; Gadjil et al., 1993). Indigenous societies have contributed a fundamental role in maintaining a harmonious and dynamic relationship with biodiversity. Moreover, Ogar et al (2020) urges Western science to embrace indigenous knowledge in 
solving biodiversity crises around the globe. The fact that indigenous peoples have been occupying and settling down within biodiversity hotspots makes their knowledge system unique and holistic. Centuries of interaction and experience enable indigenous peoples to understand and internalise their world. When it comes to natural resource management and biodiversity conservation, a wealth of empirical evidences supports the importance of indigenous knowledge.

Due to its oral and practical nature, there is a great concern about the loss of indigenous knowledge. On a more serious note, Wilder et al (2016) further assert that indigenous knowledge is turning more critical as biodiversity is declining. However, it remains a challenge to estimate the rate of loss of indigenous knowledge as there is no sufficient empirical data to evaluate the loss of indigenous knowledge components of a given population change over time (Reyes-García et al., 2014). In reality, lack of empirical data should not discredit the fact that various parts of indigenous knowledge are disappearing and discontinued.

Indigenous knowledge transfer refer to the process of transferring and reproducing cultural items such as technology, knowledge, skills, behaviours, language and beliefs from one individual to another (Cavalli-Sforza \& Feldman, 1981; Ohmagari \& Berkes, 1997). It involves parents, elders, peers, the prestigious and the majority (Calvet-mir et al., 2016). In the existing literature regarding indigenous knowledge transfer, scholars mainly refer to the work of Cavalli-Sforza \& Feldman (1981) who proposed non-mutually exclusive models known as vertical, horizontal, and oblique transmission. First model (vertical transmission) refers to knowledge transfer from parent to child, second model (horizontal transmission) refers to knowledge transfer between individuals of the same generation or peers, and third model (oblique transmission) refers to knowledge transfer from older to younger generations. Cavalli-Sforza and Feldman (1981) further discussed that the rate of knowledge diffusion in a population varies in each model. Vertical transmission is highly conservative and results in slow knowledge and innovation transfer in a population. In contrast, horizontal and oblique transmission are associated to rapid knowledge and innovation transfer as it involves various transmitters to one receiver. These models are more likely to generate a higher uniformity of knowledge and allow generational cultural change as long as contact between individuals remain constant (Cavalli-Sforza \& Feldman, 1981; Paniagua-Zambrana et al., 2016; ReyesGarcía et al., 2016). Through these models, indigenous knowledge is being transferred by various approaches such as own experimentation, teaching, emulation, and collaborative teaching (Calvet-mir et al., 2016). To better understand indigenous knowledge transfer, it is important to note that it is context dependent as highlighted by Hewlett et al (2011). It takes into account about the knowledge or skills to be transferred or the age in which knowledge is learnt (Calvet-mir et al., 2016)

Indigenous knowledge transfer is as vital as the indigenous knowledge itself. Various studies demonstrated that continuing knowledge transfer benefit the livelihood of indigenous peoples in times of disturbances and change (Berkes, 2008; Colding et al., 2003; PaniaguaZambrana et al., 2016). Tongkul (2002) reported that indigenous knowledge in biodiversity conservation include the practices in traditional medicine, river management, hunting, and farming. However, in our previous study in this area, we found that indigenous knowledge in biodiversity conservation was actively transferred with regard to practices in traditional medicine and river management (Anis Amalina et al., 2019). This situation implies that 
indigenous knowledge is eroding beyond one's consciousness. This present study reports our findings with regards to approaches of indigenous knowledge in a contemporary indigenous society involving Bajau and Dusun in Kota Belud. Following that, we also discuss some of the factors that impair the process of knowledge transfer and conclude with some practical implications.

\section{Methodology}

This study was conducted in Kota Belud, a district located in northern part of Sabah. Kota Belud covers an area of 1,1391-kilometre square with a total population of 111,800 people. Its population is made up of various ethnicities such as Dusun Tindal, Bajau Sama, Iranun and Ubian scattering the various geographical areas in Kota Belud.

This study applied qualitative research to generate an in-depth understanding on indigenous knowledge transfer. This research design allowed for informants' multiple perspectives and meaning, hence detailed and rich information on the issue under investigation could be produced.

This study involved a total of six informants $(n=6)$ (see Table 1 ) in which were selected by purposive and snowball sampling. Purposive sampling was applied in the initial stage of fieldwork based on literature study. Whilst, snowball sampling was applied the site with the advice of Native Chiefs of Kota Belud.

Table 1: Informant profile

\begin{tabular}{|c|l|l|l|l|}
\hline No. & Informant Code & Ethnicity & Age & Background \\
\hline 1. & B1 & \multirow{2}{*}{ Bajau } & 53 & Traditional medicine practitioner \\
\hline 2. & B2 & 73 & Native Chief \\
\hline 3. & D1 & Dusun & 56 & Head of local NGO \\
\hline 4. & D2 & & 55 & Member of local NGO \\
\hline 5. & D3 & & 52 & Member of local NGO \\
\hline 6. & D4 & & 67 & Native Chief \\
\hline
\end{tabular}

Data collected by using semi-structured interviews and observation during fieldwork. Data generated in the form of audio recordings were then transcribed and analysed thematically to answer the proposed research question in this study.

\section{Findings and Discussion}

\section{Approaches in Indigenous Knowledge Transfer Customary law}

Customary law is a set of law, socially embedded within the life of indigenous community and dictates the behaviours, practices, and beliefs. It is also locally known as hukum adat. Despite modernisation and development taking place, indigenous peoples continuously adhere to this law. Hence, indigenous peoples in Kota Belud considered customary law as an approach in knowledge transfer. For context, indigenous peoples in Kota Belud took the initiative to conserve some areas that deemed biologically rich in flora and fauna, culturally significant, and economically important to them. One prominent practice found is tagal sungai, a community-based and integrated river management that serves to conserve freshwater fish species and its surrounding nature from anthropogenic activities. A concept called sogit or hukum adat (peace offering) was introduced and more importantly it was gazetted in Native 
Customary Laws 1992. Essentially, such a ruling gives lessons to both locals and outsiders on the importance of their customs and traditions. Therefore, this study demonstrated that maintaining and upholding indigenous peoples' customary law retains the pathway of knowledge transfer among indigenous communities in Kota Belud.

"We have our Native Court. Native Court documents almost all of the customs belong to Dusun and other natives. If the younger and older generation abused our traditions, I think it's a guarantee that they can't arbitrarily neglect the tradition." (D1)

"One way to maintain [indigenous] practices are through customs and traditions. Tagal in the river for example. Anyone who is found guilty intruding, sogit is imposed by [the value of] one buffalo, one cow. I believe this is the way it's maintained." (D2)

Implementation of customary laws at indigenous and community conserved areas promote both biodiversity conservation and indigenous knowledge maintenance (Arjjumend \& Beaulieu-Boon, 2018). It is not denied that some customs have been abandoned, nevertheless the remaining of them are still being practiced. In this situation, it is a win situation for indigenous peoples that their customary law is codified and structurally managed by the Native Court. Indigenous peoples may directly refer to the documented materials and the process of knowledge transfer takes place.

\section{Parental Role}

It is universally accepted that parents are the principal educators to their children. Parents are also among the first members whom the children constantly communicate and engage with in various aspects of life. The role of indigenous parents in knowledge transfer is crucial as they share their context with their children especially with regards to indigenous worldviews, histories, and livelihood activities (Eyssartier et al., 2008; Hewlett \& CavalliSforza, 1986) throughout infancy, childhood and pre-adolescent stages. As most of indigenous peoples in Kota Belud abandoned indigenous livelihood, knowledge transfer from parents to children was declined. In this study, an indigenous woman who was a practitioner in traditional medicine passed her knowledge to her daughters.

"Only my children. The girls. My relatives, too. And my customers, so I would show them [how to make jamu]." (B1)

As children's first teachers, knowledge transfer from parents to children through informal education is significant to maintain and preserve indigenous knowledge (Wotherspoon, 2015). Studies by Eyssartier et al (2008) and Mathez-Stiefel \& Vandebroek (2012) in acquisition of indigenous knowledge with regards of biodiversity conservation indicate that parents are the primary source of knowledge. In this approach, children learn most about indigenous knowledge through experiential participation and observation in traditional activities such as harvesting forest products and agricultural practices (Boog et al., 2017).

\section{Cultural Events}

Cultural events such as social practices, rituals and festivals are habitual activities integral in the indigenous communities (UNESCO, 2018). They are not confined to formal gatherings having a group of audience to sit and listen to speakers. Cultural events of indigenous peoples are interactive and engaging, attracting indigenous peoples to maintain, revive and share 
their cultural maintenance (Higgins-Desbiolles, 2016). In this case, cultural events were used as an approach in transfer of indigenous knowledge to mainly attract the younger generation with regards of their culture.

"We should probably organise a contest on [the traditional practices of traditional farming] focusing on the functions of the equipment. Younger generation has easily forgotten what their precedents had set up." (B2)

One of the unique features of indigenous peoples in Kota Belud is their weekly market known as tamu. Tamu is an open-spaced market for selling the goods. These days, tamu is not only a place for trade, but a tourist attraction, too. As a long tradition of indigenous peoples, tamu was seen capable for indigenous knowledge transfer as indigenous peoples of various ethnicities and religious beliefs gathered under one roof.

"This is something I believe the public may accept. One instance is the big tamu. I notice whenever there's any cultural event or gathering, people would remain and stay until the end." (B2)

Some indigenous community also self-initiated their own small-scale cultural events like workshops and short courses, often with partnership of government and non-governmental bodies.

"So, activities we engage the community with including workshops on environmental awareness. Any related courses. For example, fish conversation campaign. People in most villages have been exercising that. Second, Kadamaian Bersih dan Indah campaign. We do communal cleaning work, not only adults but children tag along as well. Third, together with Department of Health. On preventing infectious diseases." (D1)

Cultural events have been broadly studied from cultural, social and economic perspectives however not much from has been studied from socio-ecological perspective (Saxena, 2020) like this study did. Indigenous peoples in Kota Belud were constantly involved in cultural events such as weekly tamu, Kaamatan (rice harvest) festival and commemoration of river tagal. These cultural events were the source of indigenous knowledge itself, in which indigenous communities gathered and shared information on indigenous knowledge. Provided these events are supported and mobilised collectively by the indigenous peoples, they do not only maintain the practice of indigenous knowledge but also halt the erosion of biodiversity (Saxena, 2020).

\section{Barriers in Indigenous Knowledge Transfer Change of Indigenous Livelihood Practices}

Socioeconomic changes have substantially changed the landscape of indigenous peoples' livelihood. It is apparent that indigenous peoples have dissociated themselves from subsistence economy and turned to wage labour. Catalysed by the market economy, money has become essentially important in the present days and a majority of indigenous peoples preferred living paycheck to paycheck. Change of indigenous livelihood practices causes indigenous knowledge skills and practices to be less visible. 
"The culture of earning wage has been engrained in the mind of young people. It means, it is much better as they receive monthly wages. Hence, the culture has dissipated from our youth." (B2)

In Kota Belud, change of livelihood practices can be seen in modern, high-yielding agricultural practices. This is in line with the state of government policy to brand Kota Belud as the rice bowl (jelapang padi) in Sabah. Through this effort, various government incentives and subsidies in the form of research and development, tractors services, irrigation and drainage system, and maintenance of rice quality, are being introduced to boost the production of paddy.

"Farming here has shifted focus to cash crops like rubber, coconut and palm oil trees. In Kadamaian [hilly, rural parts of Kota Belud], you can still find hill paddy farming." (B2)

"It [shifting of traditional to modern farming] began in 1980s. We stopped utilizing buffaloes, we used tractors instead. Then around 1975, [agricultural] drainage was set up. Water streamed from the river. So, we did not depend completely on the weather to start planting. All these changes did not occur all in once. From year to year, there happened some shift to modern agriculture. First was installing water drainage. Then tractors were used. In 1980s. In 1990s most seeds were obtained from Department of Agriculture. [Harvest reduced] from six months to three months. Planting did not require nursery anymore. We simply soaked the paddy and sprawled them at the paddy field. During 1970s, paddy harvesting used langgaman. Now harvesting uses machine. It took about one month to harvest paddy before, now it can be done within four hours. Then it goes for sale." (D1)

Indeed, the impacts of socioeconomic changes in indigenous peoples' livelihood exert far more complex and uneven results that one could possibly think. Godoy et al. (1998) demonstrated that cultivation of modern, high-yielding crops and wage labour substantially induce the erosion of indigenous knowledge. In the sense of knowledge transfer, change of livelihood practices brings difficulty in knowledge transfer as due to reliance to external, nonindigenous commodities and technologies (Tang \& Gavin, 2016).

\section{Change of Religious Belief}

Another situation that impedes indigenous knowledge transfer is change of religious beliefs. In Kota Belud, Bajau are mostly Muslim while Dusun are Christian. According to Halina Sandera (2017), Islam has been existing in Kota Belud prior the colonial period which was before the $19^{\text {th }}$ century. This claim was further supported with the discovery of Muslim burial ground dated back hundreds of years ago. As for the advent of Christianity, Pugh-Kitingan (2015) reported that it was spread in the 1930s. The development of these dominant religions has substantially transformed the indigenous worldview of indigenous peoples especially in terms of use of natural resources.

"During 1930s, white men [missionaries] started spreading Christianity in Kota Belud. Gradually, such belief [belief of spirit] evaporated, among the coming generations. For instance, the practice of bonbon at orchards for the whole village. Now people 
disregard that kind of practice. The same goes for other cultural traditions. They just merely exist without much significance." (D3)

Change of religious belief has also led indigenous peoples to unsustainable use natural resources. There were reported cases of illegal hunting of wildlife such as pangolins in the state protected forests. This irresponsible act was carried out due to leisure and consumption basis as well as fulfilling the demand of exotic species in the black market. Animal traps were seen installed in the forests despite the enactment of Wildlife Act 1972, which prohibit any act of illegal exploitation of wildlife in protected areas.

"Other examples in traditional hunting in the forest. Although many have realised hunting leads to wildlife extinction. Hunting becomes a favourite activity, too. Hunting pangolins is an activity among people here. We encounter some of the traps installed." (D1)

Indigenous belief is usually manifested in taboos, totems, social conducts, and cultural morals. It essentially dictates one behaviour in every aspect of life including his relationship with the natural environment. The core values of indigenous belief are respect, care as well as give and take to maintain a harmonious balance between the good and the bad spirits (Tongkul, 2002). Now, with the development of Christianity and Islam, indigenous peoples gradually disown indigenous belief, as it is contradictory to the religious teaching especially when it comes to supernatural beings.Berkes (2008) pinpointed that indigenous belief is the foundation that shapes all other aspects of indigenous knowledge. In this context, change of religious belief can be seen in the conversion to other dominant religions and loss of indigenous belief among indigenous peoples in Kota Belud. This critically influenced the way indigenous peoples managed their natural resources as they are disconnected from the concept of oneness with nature. This fundamentally disintegrates indigenous peoples from the process of knowledge transfer.

\section{Contact with Dominant, Non-indigenous Societies}

Most of indigenous societies are no longer geographically isolated, as communication and transportation are made more easily accessible. This essentially has enabled indigenous peoples to establish cross-cultural contact with other indigenous and non-indigenous groups alike. In general, the demographic landscape of Sabah significantly changed during the administration of British North Borneo Chartered Company by allowing mass entries of nonAustronesia labours into the state. The establishment of Malaysia in 1963 further escalated the immigration (most was illegal) of Tausug and Ubian people of Philippines as well as Bugis, Toraja and Flores people of Indonesia (Pugh-Kitingan, 2016). Contact between indigenous peoples and non-indigenous groups led to cross-cultural marriages, which are common in Kota Belud. In this case, cross-cultural marriages happen in two situations, indigenous/indigenous marriage of different ethnics and indigenous/non-indigenous marriage. In this case, marriage between two different indigenous groups was not considered a barrier in knowledge transfer considering they understand the customs and traditions.

"Relating to customs and traditions, I don't think that mixed marriage is a barrier. Except, for example, I married a Malay and migrated elsewhere. Our children might be 
inclined to forget their root. Staying at that same area, I view they could uphold the customs and traditions as long as those are not against religion." (D1)

On the contrary, indigenous/non-indigenous marriages are perceived to impede knowledge transfer. This situation encouraged migration to a new location and changed the traditional livelihood practices (e.g. speaking in native language, attending cultural festivals) (Tang \& Gavin, 2016). Parsonson (1987, p. 365) further demonstrated that parents that sustained a weak cultural identity, their children were likely to sustain a weak identity as well due to lack of ethnic socialisation. For example, an indigenous woman who married a Western man might not be able to transmit knowledge to her children who were moulded by Western culture and neglected their cultural root from their mother.

"Mixed marriage. From my encounter with someone whom I wasn't aware a Dusun. She said it's not her intention to leave her village and neglect the traditions, since her husband was a non-Malaysian, she had to be with him abroad. Her children did not look like Dusun. She, herself, changed her look. Blonde hair. One thing I remember that she was able to speak Dusun despite conversing in English with her children and husband. She said she had not been home for 21 years. She mentioned her children did not understand the Dusun culture. She did, could speak her mother tongue." (D4)

As mentioned above, communication and telecommunication allowed access with the outside world, hence indigenous peoples were becoming more reliant on technologies. This phenomenon could be observed in every age cohort of indigenous societies, but it is more prominent among indigenous youth. Exposure to foreign, non-indigenous cultures and dogmas through mass media discouraged indigenous peoples to learn about their own culture (Tang \& Gavin, 2016).

"From what I can see, traditions and customs are gradually diminishing. First, it's the foreign culture. From my own experience, my children who migrate out of state, seem they have lost their root. It's all urban culture. The white people culture. They even boast "Our culture is out of date!" Therefore, it's the foreign culture. And peer pressure. And the latest should be mass media. These mobile phones, modern applications." (D4)

In essence, this study presented that contact with other cultural dominant groups occurred deliberately by non-indigenous groups and voluntarily by indigenous groups. A study by Heard et al. (2009) also supported cultural contact would destroy cultural identity of indigenous peoples. This situation brings difficulty in indigenous knowledge transfer as indigenous peoples, the holder of knowledge, were more inclined to non-indigenous, dominant culture.

\section{Loss of Indigenous Institutions}

Indigenous institutions are a fundamental component in indigenous communities. Its main principle, as Kipuri (2009) mentioned "to determine the way people in a given society organise themselves in order to functions as a distinct communities, differentiated from other by specific rules, obligations, and patterns of behaviours". In Sabah, the famously known indigenous institution is Native Court (Mahkamah Anak Negeri), constitutionalised in 1913 (Azlizan \& Salbiya, 2020) which functions as a unit to settle breach of customary law among the natives in the state (Rafidah, 2014). In this context of this study, indigenous institutions 
refer to any groups or establishments formed on the initiatives of indigenous peoples themselves. Indigenous institutions are considered a key player in knowledge transfer because they portray indigenous peoples' worldviews and collective perspectives with regards of relationship between the community, nature and ancestors (Kipuri, 2009). In Kota Belud, the existence of indigenous institutions was said to receive funds without properly engaging indigenous communities with cultural activities.

"Talking about organisation, regardless of what ethnic group, it ought to be emphasised. It's rather unfortunate, these organisations are established to merely seek profits. It would be far better if these organisations put some efforts in reviving our history." (B2)

Indigenous institutions have the potential as a mechanism for effective knowledge transfer (Tengo \& Heland, 2011; Wedajo et al., 2019). We justify that the Native Court should not be the sole identity as its authority is restricted to administrative matters. In this case, role of indigenous institution is emphasised as a cultural capital, on the basis that it provides a medium of interaction and adaptation between the community and their environment as suggested by Berkes and Folke (1993). Given these indigenous institutions were already recognised by the state, they could advocate initiating plans and program to maintain the continuity of indigenous knowledge.

\section{Conclusion}

The findings in this study provide insight for approaches taken by indigenous peoples in Kota Belud in indigenous knowledge transfer. In essence, those approaches leaned towards their culture and traditions by emphasising the role and capacity of indigenous communities especially with the involvement of Native Court and customary laws. Albeit appearing less urbanised and developed, Kota Belud is inevitably transforming in terms of cultural, social, and economic aspects. Hence, such changes may impede knowledge transfer among indigenous peoples. Indigenous knowledge portrays holistic and integrated conservation ethnics of protecting various flora and fauna and maintaining cultural values and identity as long as indigenous peoples continue their stake in it. In this regard, we recommend community empowerment and active participation of indigenous peoples to maintain the indigenous knowledge transfer by taking more proactive steps in enhancing the existing approaches and addressing the challenges. This could be executed by planning and organising community-level trainings, discourses and related activities. We also recommend expanding networking and reaching out to related organisations especially with regards of expertise and funding. Moreover, networking concomitantly delivers encouraging socioeconomic effects between groups who share the common cause. It is our hope that the findings from this study propel state government, non-governmental indigenous groups and fellow researchers alike to pay more attention regarding the state of indigenous knowledge transfer.

\section{Acknowledgements}

This research has been generously supported by Universiti Putra Malaysia's Putra Grant Putra Graduate Initiative Grant (GP 9660600). The authors would like to extend immense gratitude to the people of Kota Belud, especially those at the Kota Belud Native Court and villagers, who welcomed us and made this research possible. 


\section{References}

Amalina, A., Normala, O., \& Adlina, A. H. (2019). Indigenous knowledge on the tagal system and traditional medicine of the Dusun comunity in Kota Belud, Sabah. In H. H. Mohd Nur Hidayat, E. Jawing, M. Nadiawati, N. Archie, Be. Tobi, J. L. M. Hwa, M. Y. Mohd Taqwuddin, \& W. Hiew (Eds.), Prosiding Persidangan Serantau Peradaban dan Etnik (pp. 94-101). Pusat Penataran Ilmu Bahasa, Universiti Malaysia Sabah.

Arjjumend, H., \& Beaulieu-Boon, H. (2018). Customary Institutions and Rules underlying Conservation Functions of Sacred Sites or Indigenous and Community Conserved Areas. Grassroots Journal of Natural Resources, 1(2), 1-12.

https://doi.org/10.33002/nr2581.6853.01021

Azlizan, M. E., \& Salbiya, J. (2020). Pentadbiran British di Sabah: Kesejahteraan Anak Negeri melalui penubuhan Mahkamah Anak Negeri 1884-1965. Malaysian Journal of Society and Space, 16(1), 155-167. https://doi.org/10.17576/geo-2020-1601-12

Berkes, F., \& Folke, C. (1993). A system perspective on the interrlations between natural, human-made and cultural capital. Ecological Economics, 5(1), 1-8.

Berkes, F. (2008). Sacred Ecology (Second). Routledge.

Borrelli, N., \& Davis, P. (2012). How culture shapes nature: Reflection on ecomuseum practices. Nature and Culture, 7(1), 31-47. https://doi.org/10.3167/nc.2012.070103

Calvet-mir, L., González-puente, M., Calvet-mir, L., Riu-bosoms, C., González-puente, M., Ruiz, I., Reyes-garcía, V., \& Molina, J. L. (2016). The Transmission of Home Garden Knowledge: Safeguarding Biocultural Diversity and Enhancing Social-Ecological Resilience. Society \& Natural Resources, 29(5), 556-571.

https://doi.org/10.1080/08941920.2015.1094711

Cavalli-Sforza, L. L., \& Feldman, M. W. (1981). Cultural transmission and evolution: A quantitative approach. Princeton University Press.

Colding, J., Elmqvist, T., \& Olsson, P. (2003). Living with disturbance: building resilience in social-ecological systems. In Navigating social-ecological systems: building resilience for complexity and change (pp. 163-185). Cambridge University Press, UK.

Davis, P. (2011). Ecomuseums: A sense of place. Continuum International Publishing Group.

Eyssartier, C., Ladio, A. H., \& Lozada, M. (2008). Cultural Transmission of Traditional Knowledge in two populations of North-western Patagonia. Journal of Ethnobiology and Ethnomedicine, 4(25), 4-25. https://doi.org/10.1186/1746-4269-4-25

Gadjil, M., Berkes, F., \& Folke, C. (1993). Indigenous Knowledge for Biodiversity Conservation. Ambio, 22(2), 151-156.

Garavelli, A. C., Gorgoglione, M., Scozzi, B. (2002). Managing knowledge transfer by knowledge technologies. Technovation, 22(5), 269-279. https://doi.org/10.1016/s01664972(01)00009-8

Godoy, R., Brokaw, N., Wilkie, D., Colón, D., Palermo, A., Lye, S., \& Wei, S. (1998). Of trade and cognition: Markets and the loss of folk knowledge among the Tawahka Indians of the Honduran rain forest. Journal of Anthropological Research, 54(2), 219-233. https://doi.org/10.1086/jar.54.2.3631731

Sandera, H. M. Y. (2017). Pengaruh Budaya Tradisi dan Islam dalam Evolusi Adat dan Ritual Kematian Komuniti Bajau (The Influence of Traditional Culture and Islam in Evolutionary Transformation of Death Customs and Rituals among Bajau Community). Akademika, 87(3), 33-48.

Heard, G., Birrell, B., \& Khoo, S. (2009). Intermarriage between indigenous and nonindigenous Australians. People and Place, 17(1), 1-14. 
Hewlett, B. S., \& Cavalli-Sforza, L. L. (1986). Cultural Transmission among Aka Pygmies. American Anthropologist, 88(4), 922-934.

https://doi.org/10.1525/aa.1986.88.4.02a00100

Hewlett, B. S., Fouts, H. N., Boyette, A. H., \& Hewlett, B. L. (2011). Social learning among Congo Basin hunter - gatherers. Phil. Trans. R. Soc. B, 366, 1168-1178.

https://doi.org/10.1098/rstb.2010.0373

Higgins-Desbiolles, F. (2016). Sustaining spirit: a review and analysis of an urban Indigenous Australian cultural festival. Journal of Sustainable Tourism, 24(8-9), 1280-1297. https://doi.org/10.1080/09669582.2016.1149184

Kipuri, N. (2009). Culture. In Department of Economic and Social Affairs (Ed.), DESA State of the World's Indigenous Peoples (pp. 51-78). Department of Economic and Social Affairs, United Nations.

Liu, Z., \& Lee, Y. (2015). A method for development of ecomuseums in Taiwan. Sustainability, 7, 13249-13269. https://doi.org/10.3390/su71013249

Malaysia Department of Statistics. (2019). Laporan Sosioekonomi Negeri Sabah 2019.

Mathez-Stiefel, S.-L., \& Vandebroek, I. (2012). Distribution and Transmission of Medicinal Plant Knowledge in the Andean Highlands : A Case Study from Peru and Bolivia. EvidenceBased Complementary and Alternative Medicine, 2012, 1-19. https://doi.org/10.1155/2012/959285

Ogar, E., Pecl, G., \& Mustonen, T. (2020). Science Must Embrace Traditional and Indigenous Knowledge to Solve Our Biodiversity Crisis. One Earth, 3(2). https://doi.org/10.1016/j.oneear.2020.07.006

Ohmagari, K., \& Berkes, F. (1997). Transmission of Indigenous Knowledge and Bush Skills among the Western James Bay Cree Women of Subarctic Canada. Human Ecology, 25(2), 197-222. https://doi.org/10.1023/A:1021922105740

Paniagua-Zambrana, N., Cámara-Leret, R., Bussmann, R. W., \& Macía, M. J. (2016). Understanding transmission of traditional knowledge across north-western South America: a cross-cultural study in palms (Arecaceae). Botanical Journal of the Linnean Society, 182(2), 480-504. https://doi.org/10.1111/boj.12418

Parsonson, K. (1987). Intermarriages: Effects on the Ethnic Identity of the Offspring. Journal of Cross-Cultural Psychology, 18(3), 363-371.

https://doi.org/10.1177/0022002187018003006

Pugh-Kitingan, J. (2015). Cultural and Religious Diversity in Sabah and Relationships with Surrounding Areas. In I. Tokoro, H. Tomizawa, T. G. Daigaku, \& A. A. G. B. Kenkyujo (Eds.), Islam and Cultural Diversity in Southeast Asia (pp. 269-294). Research Institute for Languages and Cultures of Asia and Africa, Tokyo University of Foreign Studies.

Pugh-Kitingan, J. (2016). Kadazandusun. Institut Terjemahan \& Buku Malaysia Berhad.

Rafidah, S. (2014). Native Courts System in Sabah: Will it Continue to Survive? International Conference on Law, Policy and Social Justice (ICLAPS 2014).

https://doi.org/10.13140/2.1.1674.4005

Reyes-García, V., Gallois, S., \& Demps, K. (2016). A Multistage Learning Model for Cultural Transmission: Evidence from Three Indigenous Societies. In H. Terashima \& H. Hewlett (Eds.), Social Learning and Innovation in Contemporary Hunter-Gatherers. Replacement of Neanderthals by Modern Humans Series (pp. 47-60). Springer, Tokyo. https://doi.org/10.1007/978-4-431-55997-9

Reyes-García, V., Guèze, M., Luz, A. C., Paneque-Gálvez, J., Macía, M. J., Orta-Martínez, M., Pino, J., \& Rubio-Campillo, X. (2014). Evidence of traditional knowledge loss among a 
contemporary indigenous society. Evolution and Human Behavior, 34(4), 249-257. https://doi.org/10.1016/j.evolhumbehav.2013.03.002

Saxena, L. P. (2020). Community self-organisation from a social-ecological perspective: 'Burlang Yatra' and revival of millets in Odisha (India). Sustainability (Switzerland), 12(5), 1-27. https://doi.org/10.3390/su12051867

Tang, R., \& Gavin, M. C. (2016). A Classification of Threats to Traditional Ecological Knowledge and Conservation Responses. Conservation and Society, 14(1), 57-70.

Tengo, M., \& Heland, J. Von. (2011). Adaptive capacity of local indigenous institutions: The case of the taboo forests of southern Madagascar. In Adapting Institutions: Governance, Complexity and Social-Ecological Resilience (Vol. 6, Issue 1, pp. 37-74). Routledge. https://doi.org/10.1017/CBO9781139017237.006

Tongkul, F. (2002). Traditional Systems of Indigenous Peoples of Sabah, Malaysia. PACOS Trust.

UNESCO. (2018). Basic Texts of the 2003 Convention for the Safeguarding of the Intangible Cultural Heritage 2018 Edition. https://doi.org/10.1093/rsq/10.2.88

United Nations. (1992). Convention on biological diversity. Diversity, 30. https://doi.org/10.1146/annurev.ento.48.091801.112645

Wan Arfah, H., \& Ramy, B. (2003). An introduction to the Malaysian legal system. Fajar Bakti.

Wedajo, D. Y., Belissa, T. K., \& Jilito, M. F. (2019). Harnessing indigenous social institutions for technology adoption: 'Afoosha' society of Ethiopia. Development Studies Research, 6(1), 152-162. https://doi.org/10.1080/21665095.2019.1678187

Wilder, B. T., O'Meara, C., Monti, L., \& Nabhan, G. P. (2016). The Importance of Indigenous Knowledge in Curbing the Loss of Language and Biodiversity. BioScience, 66(6), 499-509. https://doi.org/10.1093/biosci/biw026

Wong, D. (2009). Wooley and the codification of native customs in Sabah. New Zealand Journal of Asian Studies, 11(1), 87-105.

Wotherspoon, T. (2015). Formal and Informal Indigenous Education. In W. Jacob, S. Cheng, \& M. Porter (Eds.), Indigenous Education. Springer. https://doi.org/10.1007/978-94-0179355-1_4 